\title{
PENGARUH KENAIKAN GAJI PNS TERHADAP KORUPSI YANG DITANGANI OLEH KOMISI PEMBERANTASAN KORUPSI (KPK)
}

\author{
Abdul Sani \\ saniabdul30@gmail.com \\ Badan Kepegawaian dan Pengembangan Sumber Daya Manusia Daerah \\ Provinsi Kepulauan Bangka Belitung
}

\begin{abstract}
ABSTRAK
This study aims to determine the effect or relationship between the increase in salaries of civil servants against corruption. The method used in this research is quantitative method using statistical analysis of descriptive and analytic statistics. Data used in this research is secondary data from 2008 to 2017 obtained from Corruption Eradication Commission (KPK) and Ministry of Administrative Reform and Bureaucracy Reform (Kemenpan RB). Data analysis using linear regression. Result of data analysis that is $R$ Square: 0.085295 indicate that there is no correlation or influence of salary increase of civil servant with corruption. While Significance F: 0.44571782 this shows that the effect of pay increases on corruption is not significant. With this research is expected to have a more comprehensive strategy in eradicating corruption.

Penelitian ini bertujuan untuk mengetahui pengaruh atau hubungan antara kenaikan gaji PNS dan korupsi. Metode yang digunakan dalam penelitian ini adalah Metode kuantitatif dengan menggunakan analisis statistik deskriptif dan statistik analitik. Data yang digunakan dalam penelitian ini adalah data sekunder dari tahun 2008 sampai 2017 yang diperoleh dari Komisi Pemberantasan Korupsi (KPK) dan Kementerian Pendayagunaan Aparatur Negara dan Reformasi Birokrasi (Kemenpan RB). Analisis data menggunakan regresi liner. Hasil analisis data, yaitu R Square: 0.085295, menunjukkan bahwa tidak ada hubungan atau pengaruh kenaikan gaji PNS dengan korupsi. Adapun significance F: 0.44571782, ini menunjukkan bahwa pengaruh kenaikan gaji terhadap korupsi tidak signifikan. Dengan penelitian ini diharapkan ada strategi lain yang lebih komprehensif dalam pemberantasan tindak pidana korupsi.
\end{abstract}

Kata Kunci: Kenaikan gaji, Korupsi

\section{PENDAHULUAN}

Praktik korupsi yang terjadi di mana-mana merupakan fakta yang tidak terbantahkan. Perkembangannya terus meningkat dari tahun ke tahun, baik dari jumlah kasus yang terjadi dan jumlah kerugian keuangan negara maupun dari segi kualitas tindak pidana yang dilakukan semakin sistematis serta lingkupnya yang memasuki seluruh aspek kehidupan masyarakat.

Meningkatnya tindak pidana korupsi baik dari segi kualitas maupun kuantitas yang begitu rapi telah menyebabkan terpuruknya perekonomian Indonesia. Korupsi di Indonesia bagaikan gurita. Penyimpangan ini bukan saja merasuki kawasan yang sudah dipersepsi publik sebagai sarang korupsi, namun juga menyusuri lorong-lorong instansi yang tak terbayangkan sebelumnya bahwa ada tindakan korupsi.

Dengan semakin berkembangnya sektor ekonomi dan politik serta semakin majunya usahausaha pembangunan dengan pembukaan-pembukaan sumber daya alam yang baru, maka semakin kuat dorongan individu terutama di kalangan pegawai negeri untuk melakukan praktik korupsi.

Meningkatnya tindak pidana korupsi yang tidak terkendali akan membawa bencana tidak saja terhadap kehidupan perekonomian nasional tapi juga terhadap kehidupan berbangsa dan bernegara pada umumnya. Tindak pidana korupsi yang meluas 
dan sistematis juga merupakan pelanggaran terhadap hak-hak sosial dan hak-hak ekonomi masyarakat. Oleh karena itu, maka tindak pidana korupsi tidak lagi dapat digolongkan sebagai kejahatan biasa tapi telah menjadi kejahatan luar biasa. Begitu pula dalam upaya pemberantasannya, tidak lagi bisa dilakukan secara biasa tapi dituntut cara-cara yang luar biasa. Salah satu faktor penyebab orang melakukan korupsi adalah faktor ekonomi. Oleh sebab itu perlu dilakukan penelitian tentang hubungan korupsi dengan kenaikan gaji terutama bagi pegawai negeri sipil (PNS).

\section{URAIAN PENELITIAN}

\section{Pengertian Gaji PNS}

Undang-undang Nomor 5 Tahun 2014 tentang Aparatur Sipil Negara (ASN) mengamanatkan bahwa pemerintah wajib membayar gaji yang adil dan layak kepada PNS serta menjamin kesejahteraan PNS. Komponen gaji yang diterima PNS hanya terdiri dari tiga macam, yaitu gaji, tunjangan kinerja, dan tunjangan kemahalan. Gaji adalah kompensasi dasar berupa honorarium sesuai dengan beban kerja, tanggung jawab jabatan dan risiko pekerjaan yang ditetapkan oleh peraturan perundang-undangan. Tunjangan kinerja dibayarkan sesuai pencapaian kinerja. Adapun tunjangan kemahalan dibayarkan sesuai dengan tingkat kemahalan berdasarkan indeks harga yang berlaku di daerah masing-masing. Dalam penelitian ini penulis hanya fokus terhadap gaji.

\section{Pengertian Korupsi}

Korupsi berasal dari bahasa Latin, corruptio dari kata kerja corrumpere yang berarti busuk, rusak, menggoyahkan, memutarbalikkan, menyogok. Menurut Transparency International, korupsi adalah perilaku pejabat publik, baik politikus/politisi maupun pegawai negeri, yang secara tidak wajar dan tidak legal memperkaya diri atau memperkaya mereka yang dekat dengannya, dengan menyalahgunakan kekuasaan publik yang dipercayakan kepada mereka.

Menurut Undang-undang No. 31 Tahun 1999 tentang Pemberantasan Tindak Pidana Korupsi, yang termasuk dalam tindak pidana korupsi adalah: "Setiap orang yang dikategorikan melawan hukum, melakukan perbuatan memperkaya diri sendiri, menguntungkan diri sendiri atau orang lain atau suatu korporasi, menyalahgunakan kewenangan maupun kesempatan atau sarana yang ada padanya karena jabatan atau kedudukan yang dapat merugikan keuangan negara atau perekonomian negara."

\section{Penyebab Orang Melakukan Korupsi}

Analisis yang lebih detail tentang penyebab korupsi diutarakan oleh Badan Pengawasan Keuangan dan Pembangunan (BPKP) dalam buku berjudul Strategi Pemberantasan Korupsi, yakni:

1. Aspek individu pelaku

a.Sifat tamak manusia. Kemungkinan orang melakukan korupsi bukan karena orangnya miskin atau penghasilan tak cukup. Kemungkinan orang tersebut sudah cukup kaya tapi masih punya hasrat besar untuk memperkaya diri. Unsur penyebab korupsi pada pelaku semacam itu datang dari dalam diri sendiri, yaitu sifat tamak dan rakus.

b. Moral yang kurang kuat. Seorang yang moralnya tidak kuat cenderung mudah tergoda untuk melakukan korupsi.

c. Penghasilan yang kurang mencukupi. Penghasilan seorang pegawai dari suatu pekerjaan selayaknya memenuhi kebutuhan hidup yang wajar. Bila hal itu tidak terjadi, maka seseorang akan berusaha memenuhinya dengan berbagai cara. Akan tetapi, bila segala upaya dilakukan ternyata sulit didapatkan, hal ini yang akan memberi peluang besar untuk melakukan korupsi, baik itu korupsi waktu maupun tenaga.

d. Kebutuhan hidup yang mendesak. Keterdesakan itu membuka ruang bagi seseorang untuk mengambil jalan pintas di antaranya dengan melakukan korupsi.

e. Gaya hidup yang konsumtif. Kehidupan di kotakota besar acap kali mendorong gaya hidup seseorang konsumtif. Perilaku konsumtif semacam ini bila tidak diimbangi dengan pendapatan yang memadai akan membuka peluang seseorang untuk melakukan berbagai tindakan untuk memenuhi hajatnya. Salah satu kemungkinan tindakan itu adalah dengan korupsi.

f. Malas atau tidak mau kerja. Sebagian orang ingin mendapatkan hasil dari sebuah pekerjaan tanpa keluar keringat alias malas bekerja. Sifat semacam ini akan potensial mendorong seseorang yang memilikinya untuk melakukan tindakan apa pun dengan cara-cara mudah dan cepat, di antaranya berupa tindakan korupsi.

g. Ajaran agama yang kurang diterapkan. Indonesia dikenal sebagai bangsa religius yang tentu akan melarang tindak korupsi dalam bentuk apa pun. Kenyataan di lapangan menunjukkan bila korupsi masih berjalan subur di tengah masyarakat. Situasi paradoks ini menandakan bahwa ajaran agama kurang diterapkan dalam kehidupan. 
2. Aspek organisasi

a. Kurang adanya sikap keteladanan pimpinan. Posisi pemimpin dalam suatu lembaga formal maupun informal mempunyai pengaruh penting bagi bawahan. Bila pemimpin tidak bisa memberi keteladanan yang baik di hadapan bawahan, misalnya berbuat korupsi, maka kemungkinan besar bawahnya akan mengambil kesempatan yang sama dengan atasannya.

b. Sistem akuntabilitas yang benar di instansi pemerintah yang kurang memadai. Institusi pemerintahan yang belum merumuskan dengan jelas visi dan misi yang diembannya dan juga belum merumuskan dengan tujuan dan sasaran yang harus dicapai dalam periode tertentu, menyebabkan sulit dilakukan penilaian apakah instansi tersebut berhasil mencapai sasaran ataukah tidak. Akibat lebih lanjut adalah kurangnya perhatian pada efisiensi penggunaan sumber daya yang dimiliki. Keadaan ini memunculkan situasi organisasi yang kondusif untuk praktik korupsi.

Selain itu, ada faktor-faktor lain terjadinya tindak korupsi:

1. Administrasi yang lamban;

2. Warisan pemerintahan kolonial;

3. Sikap mental pegawai yang ingin cepat kaya dengan cara yang tidak halal;

4. Tidak ada kesadaran bernegara;

5. Tidak ada pengetahuan pada bidang pekerjaan yang dilakukan oleh pejabat pemerintah.

\section{Dampak Korupsi}

Tindak pidana korupsi tak ubahnya seperti tindakan pengecut yang memanfaatkan jabatan dan posisi yang telah dipercayakan kepada seseorang. Secara psikologi, pencurian terjadi karena keadaan sosial ekonomi masyarakat yang timpang dengan tuntutan kebutuhan yang tiada pernah terhenti sehingga dengan upaya apa pun harus didapatkan penghasilan. Mencuri merupakan jalan akhir yang ditempuh untuk menutupi segala kebutuhan ini. Namun, korupsi adalah tindakan amoral yang lebih culas. Korupsi adalah penyakit birokrasi pemimpin yang harus ditanggulangi secara menyeluruh.

Secara umum, akibat korupsi adalah merugikan negara dan merusak sendi-sendi kebersamaan serta memperlambat tercapainya tujuan nasional seperti yang tercantum dalam Pembukaan Undang-undang Dasar 1945.

McMullan (1961) menyatakan bahwa akibat korupsi adalah ketidakefisienan, ketidakadilan, rakyat tidak mempercayai pemerintah, memboroskan sumber-sumber negara, tidak mendorong perusahaan untuk berusaha, ketidakstabilan politik, pembatasan dalam kebijaksanaan pemerintah, dan tindakan represif.

Adapun dampak korupsi yang lebih terperinci adalah sebagai berikut:

1. Dampak korupsi terhadap negara

a. Tata ekonomi seperti larinya modal keluar negeri, gangguan terhadap perusahaan, gangguan penanaman modal.

b. Tata sosial budaya seperti revolusi sosial, ketimpangan sosial.

c. Tata politik seperti pengambilalihan kekuasaan, hilangnya bantuan luar negeri, hilangnya kewibawaan pemerintah, dan ketidakstabilan politik.

d. Tata administrasi seperti tidak efisien, kurangnya kemampuan administrasi, hilangnya keahlian, hilangnya sumbersumber negara, keterbatasan kebijaksanaan pemerintah, pengambilan tindakan-tindakan represif.

2. Dampak korupsi terhadap masyarakat

a. Meningkatnya kemiskinan

Banyak proyek pemerintah ataupun bantuan asing untuk rakyat miskin tidak efektif akibat "disunat" oleh oknum pejabat pemerintah yang tidak bertanggung jawab. Dalam banyak kasus korupsi, masyarakat miskin sering menjadi korban karena ketidakberdayaan mereka.

b. Meningkatkan angka kriminalitas

Korupsi menyuburkan berbagai jenis kejahatan yang lain dalam masyarakat. Semakin tinggi tingkat korupsi, semakin besar pula kejahatan. Menurut Transparency International, terdapat pertalian erat antara jumlah korupsi dan jumlah kejahatan. Rasionalisasinya adalah bahwa ketika angka korupsi meningkat, maka angka kejahatan yang terjadi juga meningkat. Sebaliknya, ketika angka korupsi berhasil dikurangi, maka kepercayaan masyarakat terhadap penegakan hukum (law enforcement) juga meningkat. Dengan mengurangi korupsi, secara tidak langsung dapat juga mengurangi kejahatan yang lain.

c. Menurunkan tingkat kepercayaan masyarakat terhadap pemerintah

Bila kasus korupsi berlangsung terusmenerus, maka masyarakat akan cenderung meragukan segala hal yang berhubungan dengan pemerintah. Sebagai contoh, pemilu 
tidak akan berjalan lancar sebagaimana mestinya karena masyarakat enggan ikut berpartisipasi. Menurut masyarakat, mengikuti pemilu sama saja turut serta memilih koruptor baru. Apabila kasus korupsi dibiarkan terus-menerus, dampak korupsi yang paling besar adalah perlawanan masyarakat karena ketidakpuasan terhadap pemerintah.

3. Dampak korupsi terhadap pelaku

a. Memberikan rasa tidak tenang

Melakukan tindak korupsi tentunya akan mempengaruhi kehidupan batin dari pelakunya. Meskipun belum tentu tindakannya diketahui pihak berwajib, pelaku pasti terbayang-bayangi rasa waswas, tidak tenang selama bekerja, dan takut yang berkepanjangan karena khawatir perbuatannya diketahui umum.

b. Hukuman pidana

Bagi pejabat yang terbukti bersalah melakukan tindak pidana korupsi, maka pasti ia akan diproses oleh pihak yang berwajib. Hukuman pidana terhadap pelaku korupsi dapat berupa denda dan/atau hukuman penjara

c. Tekanan sosial seumur hidup

Bagi bekas pelaku korupsi yang selesai menjalani masa hukumannya, itu bukan berarti ia dapat hidup seperti masyarakat lain pada umumnya. Pelaku korupsi oleh khalayak ramai akan menyebabkan pelaku menanggung rasa malu seumur hidup dan terus tertekan. Setiap kegiatan yang pelaku lakukan akan distigma negatif oleh orang lain. Hal-hal apa pun yang pelaku kerjakan akan disangkutpautkan dengan korupsi. $\mathrm{Hal}$ ini akan terus melekat terhadap individu pelaku sampai dengan ia mati nanti.

\section{Langkah-langkah yang Dapat Ditempuh untuk Memberantas Korupsi}

Tugas memerangi korupsi bukan hanya ada pada Komisi Pemberantasan Korupsi atau Badan Inspektorat Negara. Korupsi akan terkikis dari bumi pertiwi ini melalui semua elemen pemerintahan, dari terendah sampai paling tinggi.

Caiden Gerald (2000) memberikan langkahlangkah untuk menanggulangi korupsi sebagai berikut:

1) Membuat struktur baru yang mendasarkan bagaimana keputusan dibuat.

2) Melakukan perubahan organisasi yang akan mempermudah masalah pengawasan dan pencegahan kekuasaan yang terpusat.

3) Rotasi penugasan.

4) Mengurangi wewenang yang saling tindih pada organisasi yang sama.

5) Membenahi birokrasi yang saling bersaing.

6) Menunjuk instansi pengawas.

7) Meningkatkan ancaman.

Kartono

menyarankan

penanggulangan korupsi dengan langkah sebagai berikut:

1) Adanya kesadaran rakyat untuk ikut memikul tanggung jawab guna melakukan partisipasi politik dan kontrol sosial.

2) Menanamkan aspirasi nasional yang positif, yaitu mengutamakan kepentingan nasional.

3) Para pemimpin dan pejabat memberikan teladan, memberantas dan menindak korupsi.

4) Adanya sanksi dan kekuatan untuk menindak, memberantas, dan menghukum pelaku tindak pidana korupsi.

5) Reorganisasi dan rasionalisasi dari organisasi pemerintah, melalui penyederhanaan jumlah departemen, beserta jawatan di bawahnya.

6) Adanya sistem penerimaan pegawai yang berdasarkan "achievement" dan bukan berdasarkan sistem "ascription".

7) Adanya kebutuhan pegawai negeri yang nonpolitik demi kelancaran administrasi pemerintah.

8) Menciptakan aparatur pemerintah yang jujur.

Menurut Mamosudjono (1989), dalam menanggulangi korupsi diperlukan sanksi mempermalukan koruptor, yaitu dengan menayangkan wajah para koruptor di televisi karena menurutnya masuk penjara tidak dianggap sebagai hal yang memalukan lagi.

Masih menurut Mamosudjono, upaya-upaya lain yang dapat memperkuat upaya di atas adalah sebagai berikut:

1) Upaya memerangi korupsi dari diri sendiri

Hal mendasar yang harus ditanamkan dalam mengendalikan diri dari kesempatan atau peluang korupsi adalah menanamkan nilai agama yang mantap pada diri sendiri. Benteng agama merupakan benteng tak tertaklukkan. Agama dibangun dari kitab yang langsung disampaikan Allah. Bagi umat Islam, mempercayakan segala tuntunan pada AlQur'an dan Rasulullah, bagi umat Hindu menjadikan Weda sebagai tuntunan, demikian pula untuk pemeluk Katolik dan Kristen dari Injil dan Budha dari Tripitaka.

Menanamkan ajaran agama yang kuat 
bahwasanya korupsi, pencurian, pembunuhan dan tindakan kriminal lainnya - termasuk ucapan seharihari kita-tidak akan lepas dari pengawasan Ilahi yang kelak akan dimintai pertanggungjawaban. Oleh karena itu, hal pertama dalam memerangi korupsi adalah upaya seseorang untuk membentengi diri dengan agama, serta tidak mencampuradukkan kebenaran agama dengan kepentingan, yang nantinya hanya akan menghancurkan sendi-sendi kebenaran agama.

\section{2) Upaya memerangi korupsi pada keluarga}

Keluarga sangat mempunyai peranan yang strategis dalam mendidik kepribadian seseorang. Keluarga harus dapat mencerminkan sikap yang berada pada rel agama, dan sikap yang harus dijauhi dari kehidupan bermasyarakat dan bernegara. Dalam hal ini keluarga harus bertindak sebagai wadah dari keteladanan. Sikap dan perilaku dalam keluarga harus menciptakan kehangatan dan keharmonisan. Kepala keluarga bertindak sebagai payung dan pemimpin yang memberikan pengarahan, ibu bertindak sebagai penampung aspirasi dan motor pendidikan anak. Upaya keluarga untuk menumbuhkan peran dan tanggung jawab kepada anak akan membuat hegemoni secara universal bahwa sesama manusia mempunyai tugas dan peran yang sama besar sesuai jabatan yang diembannya.

\section{3) Upaya memerangi korupsi oleh bangsa dan negara}

Keberadaan Inpres No. 5 Tahun 2004 tentang Percepatan Pemberantasan Korupsi di Indonesia mendorong berbagai insiatif-inisiatif di lingkungan pemerintahan pusat sampai ke daerah. Melalui Inpres ini, Presiden Republik Indonesia mengamanatkan untuk melakukan langkah-langkah upaya strategis dalam rangka mempercepat pemberantasan korupsi, salah satunya dengan menyusun Rencana Aksi Nasional Pemberantasan Korupsi (RAN-PK) 2004-2009. Dokumen RANPK 2004-2009 menekankan kepada upaya pencegahan, penindakan, upaya pencegahan dan penindakan korupsi, serta pedoman pelaksanaan monitoring dan evaluasi pelaksanaan RAN PK. Dengan demikian, RAN-PK diharapkan menjadi acuan dalam upaya pemberantasan korupsi bagi setiap lini pemerintahan di tingkat pusat dan daerah.

Dari beberapa upaya yang bisa dilakukan seperti yang dijelaskan di atas, ada beberapa strategi besar (grand strategy) yang perlu dilaksanakan, di antaranya adalah:

1. Melaksanakan upaya-upaya pencegahan;

2. Melaksanakan langkah-langkah strategis di bidang penindakan;
3. Melaksanakan harmonisasi dan penyusunan peraturan perundang-undangan di bidang pemberantasan korupsi dan sektor lainnya yang terkait;

4. Melaksanakan penyelamatan aset hasil tindak pidana korupsi;

5. Meningkatkan kerja sama internasional dalam rangka pemberantasan korupsi;

6. Meningkatkan koordinasi dalam rangka pelaporan pelaksanaan upaya pemberantasan korupsi.

Tindakan yang dapat dilakukan untuk memberantas korupsi adalah sebagai berikut:

1. Preventif

a. Membangun dan menyebarkan etos pejabat dan pegawai, baik di instansi pemerintah maupun swasta, tentang pemisahan yang jelas dan tajam antara milik pribadi dan milik perusahaan atau milik negara.

b. Mengusahakan perbaikan penghasilan (gaji) bagi pejabat dan pegawai negeri sesuai dengan kemajuan ekonomi dan kemajuan swasta agar pejabat dan pegawai saling menegakkan wibawa dan integritas jabatannya dan tidak terbawa oleh godaan dan kesempatan yang diberikan oleh wewenangnya.

c. Keteladanan dan perilaku pimpinan dan atasan lebih efektif dalam memasyarakatkan pandangan, penilaian, dan kebijakan.

d. Menumbuhkan pemahaman dan kebudayaan politik yang terbuka untuk kontrol, koreksi dan peringatan mengingat wewenang dan kekuasaan itu cenderung disalahgunakan.

e. Hal yang tidak kalah pentingnya adalah bagaimana menumbuhkan "sense of belongingness" di kalangan pejabat dan pegawai sehingga mereka merasa perusahaan tersebut adalah milik sendiri dan tidak perlu korupsi, dan selalu berusaha berbuat yang terbaik.

2. Represif

a. Menghukum para koruptor dengan hukuman yang seberat-beratnya.

b. Perlu penayangan wajah koruptor di televisi.

c. Heregistrasi (pencatatan ulang) terhadap kekayaan pejabat.

\section{METODE PENELITIAN}

Metode dalam penelitian ini menggunakan pendekatan kuantitatif. Metode kuantitatif adalah pendekatan yang di dalamnya ada usulan penelitian, proses, hipotesis, turun ke lapangan, analisis data, 


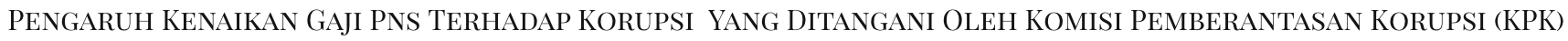
dan kesimpulan. Data disampaikan dengan mempergunakan aspek pengukuran, perhitungan rumus, dan kepastian data numerik.

Analisis data dalam penelitian ini menggunakan statistik deskriptif dan statistik analitik. Statistik deskriptif berusaha menggambarkan berbagai karakteristik data. Menurut Sugiono, yang dimaksud dengan statistik deskriptif adalah statistik yang digunakan untuk analisis data dengan cara mendeskripsikan atau menggambarkan data yang telah terkumpul dengan tidak membuat kesimpulan untuk generalisasi. Adapun yang dimaksud dengan statistik analitik adalah statistik yang digunakan untuk menganalisis data sampel, dan hasilnya akan digeneralisasikan (diinferensikan) untuk populasi tempat sampel diambil.

Statistik deskriptif harus mendahului statistik inferensi/analitik. Karena pentingnya statistik deskriptif ini, para ahli selalu mengatakan: know your data, what kind of data you have! Statistik inferensi/analitik akan mengambil kesimpulan terhadap hipotesis.

\section{HASIL DAN PEMBAHASAN}

\section{Hasil Analisis Data Penelitian}

Berikut disajikan data dan hasil pengolahan data:

Tabel 1: Tindak pidana korupsi yang ditangani oleh KPK pada 2008-2017

\begin{tabular}{|c|c|c|c|c|c|c|c|c|c|c|c|}
\hline Tahun & 2008 & 2009 & 2010 & 2011 & 2012 & 2013 & 2014 & 2015 & 2016 & 2017 & $\begin{array}{c}\text { Rata-rata } \\
\text { kenaikan } \\
\text { korupsi } \\
\text { per tahun (\%) }\end{array}$ \\
\hline Korupsi & & 0.61 & -0.08 & 0.00 & -0.18 & 0.43 & 0.00 & -0.05 & 0.87 & 0.18 & 0.20 \\
\hline
\end{tabular}

Sumber: hasil pengolahan data

Grafik 1: Korupsi pada 2008-2017

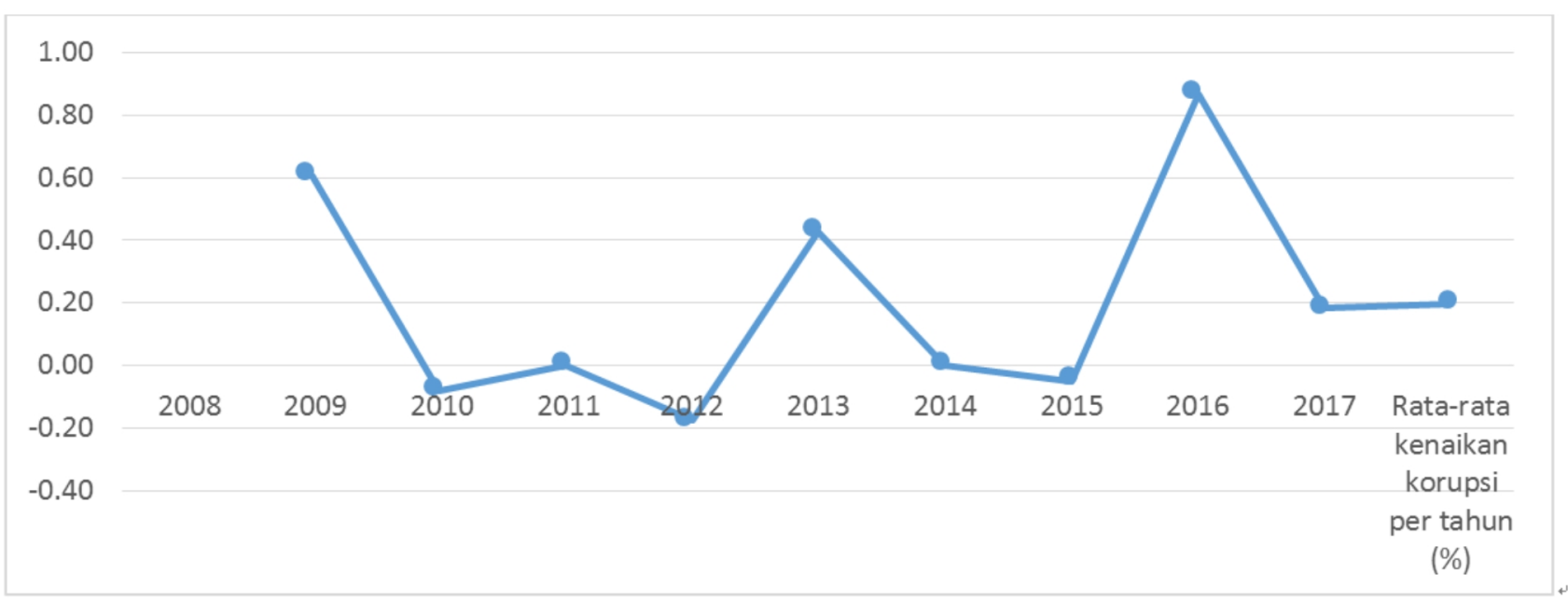

Sumber: KPK diolah peneliti

Tabel 2: Persentase kenaikan gaji pada 2008-2017

\begin{tabular}{|c|c|c|c|c|c|c|c|c|c|c|c|}
\hline Tahun & 2008 & 2009 & 2010 & 2011 & 2012 & 2013 & 2014 & 2015 & 2016 & 2017 & $\begin{array}{c}\text { Rata-rata } \\
\text { kenaikan } \\
\text { gaji } \\
\text { per tahun (\%) }\end{array}$ \\
\hline Kenaikan gaji & & 0.15 & 0.5 & 0.1 & 0.1 & 0.7 & 0.6 & 0.6 & 0 & 0 & 0.31 \\
\hline
\end{tabular}

Sumber: Tempo, diolah peneliti 
Grafik 2: Kenaikan gaji pada 2008-2017

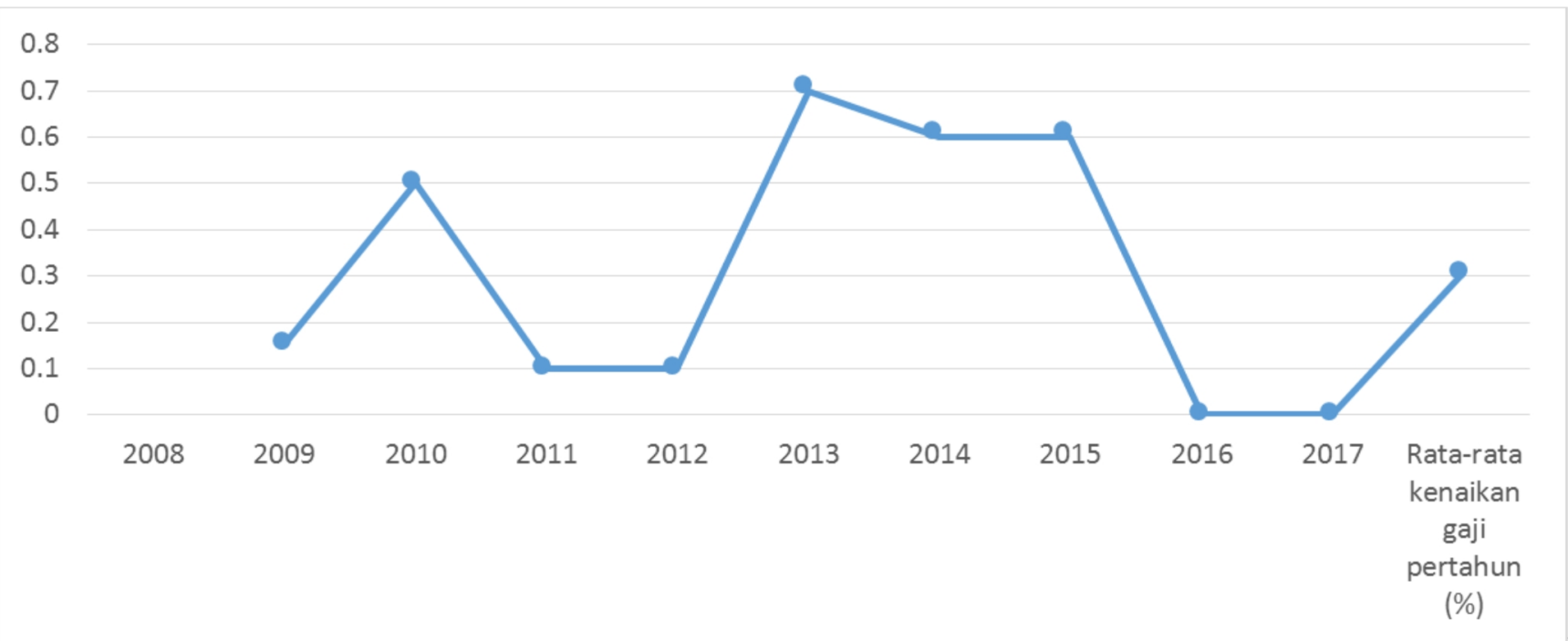

Sumber: Tempo, diolah peneliti

Tabel 3:Data Regresi Linier

\begin{tabular}{|c|c|}
\hline \multicolumn{2}{|c|}{ Regression Statistics } \\
\hline Multiple R & 0.292052848 \\
\hline R Square & 0.085294866 \\
\hline Adjusted R Square & -0.045377296 \\
\hline Standard Error & 0.37 \\
\hline Observations & 9 \\
\hline
\end{tabular}

Sumber: hasil pengolahan data 2018

Berdasarkan tabel 1 di atas dapat diperoleh $\mathrm{R}$ Square 0.085294866 , ini berarti tidak ada pengaruh antara kenaikan gaji PNS dengan korupsi.

Tabel 4: Signifikansi pengaruh

\begin{tabular}{|c|c|c|c|c|c|}
\hline \multicolumn{6}{|l|}{ ANOVA } \\
\hline & $d f$ & SS & $M S$ & $F$ & Significance $F$ \\
\hline Regression & 1 & 0.08781507 & 0.08781507 & 0.65273938 & 0.44571782 \\
\hline Residual & 7 & 0.94173188 & 0.13453313 & & \\
\hline Total & 8 & 1.02954695 & & & \\
\hline
\end{tabular}

Sumber: hasil pengolahan data 2018

Dari tabel 2 di atas dapat diperoleh nilai F 0.44571782, ini berarti tingkat hubungan antara kenaikan gaji PNS dengan korupsi tidak signifikan. 
Tabel 5: Rincian data tentang pengaruh antara variabel $X$ terhadap $Y$

\begin{tabular}{|lllllllll|} 
& Coefficients & Standard Error & t Stat & P-value & Lower 95\% & Upper 95\% & Lower 95.0\% & Upper 95.0\% \\
Intercept & 0.30918366 & 0.18416145 & 1.67887285 & 0.1370712 & -0.12628897 & 0.74465629 & -0.12628897 & 0.744656292 \\
X Variable 1 & -0.36415196 & 0.45072613 & -0.80792288 & 0.44571782 & -1.42994991 & 0.70164599 & -1.42994991 & 0.701645992 \\
\hline
\end{tabular}

Sumber: hasil pengolahan data 2018

Dari hasil tabel 3 di atas dapat diperoleh rincian hasil yang menguatkan bahwa pengaruh variabel X terhadap Y dalam hal ini pengaruh kenaikan gaji PNS terhadap korupsi sangat kecil atau tidak signifikan; ini dibuktikan dengan angka P-value sebesar 0.44571782 .

\section{Pembahasan}

Berdasarkan tabel dan grafik korupsi di atas, dapat dianalisis bahwa secara umum terjadi kenaikan dan penurunan tindak pidana korupsi yang tidak merata dari tahun ke tahun. Kenaikan secara signifikan terjadi pada 2009 dan 2016. Adapun pada tahun selain itu terjadi penurunan dan kenaikan tapi tidak terlalu signifikan. Penurunan korupsi terendah terjadi pada 2012. Sementara rata-rata kenaikan tindak pidana korupsi selama 10 tahun terakhir sebesar $20 \%$.

Berdasarkan tabel dan grafik kenaikan gaji dapat dianalisis bahwa secara umum terjadi kenaikan gaji hampir terjadi setiap tahun, kecuali pada 2016 dan 2017. Kenaikan gaji yang tertinggi terjadi pada 2013. Kenaikan gaji terendah terjadi pada 2011 dan 2012. Pada 2016 dan 2017 tidak ada kenaikan gaji sama sekali. Rata-rata kenaikan gaji setiap tahun berada pada angka 0,31\%.

Apakah kenaikan tindak pidana korupsi berhubungan dengan kenaikan gaji? Dari hasil pengolahan data di atas dapat dijelaskan pada paparan di bawah ini.

Peneliti menghubungkan antara kenaikan gaji PNS dengan korupsi. Didapatkan hasil sebagai berikut:

R Square: 0.085295 menunjukkan bahwa tidak ada pengaruh kenaikan gaji PNS dengan korupsi. Adapun significance F: 0.44571782 , ini menunjukkan bahwa tidak ada hubungan antara kenaikan gaji terhadap korupsi. Hasil ini menunjukkan bahwa hipotesis yang diajukan (H1) tidak terbukti.

\section{KESIMPULAN DAN SARAN}

\section{Kesimpulan}

Korupsi merupakan tindak pidana yang dikategorikan sebagai kejahatan luar biasa. Banyak faktor yang menyebabkan orang melakukan korupsi. Masalah ekonomi merupakan salah satu faktor yang mempengaruhi orang melakukan korupsi. Untuk kasus ini tidak ada pengaruh signifikan antara kenaikan gaji terhadap korupsi.

\section{Saran}

Hasil dari penelitian ini memang hanya sebatas menghubungkan kenaikan gaji yang ada saat ini yang kenaikannya relatif tidak terlalu besar. Dalam hal ini, pengaruh terhadap korupsi terbilang sangat kecil. Akan tetapi, jika kenaikan gaji relatif besar, maka kemungkinan ada pengaruh yang signifikan. Untuk itu, peneliti menyarankan:

1. Karena kenaikan gaji pegawai tidak ada hubungan dengan korupsi, perlu penanganan pencegahan korupsi lebih masif lagi dari segala bidang, baik sistem politik, ekonomi maupun moral spiritual.

2. Hal pertama untuk membentengi diri dari tindak pidana korupsi adalah upaya untuk kembali kepada moral pribadi yang berdasarkan nilai dan kaidah agama, serta penegakan hukum agama yang mantap di segala bidang serta dilakukan sejak usia dini.

3. Korupsi tidak diselesaikan oleh satu badan hukum, namun harus diadakan konfigurasi yang erat. Maka dari itu kepada semua kalangan diharapkan dapat turut serta mengawasi jalannya pemerintahan dan keikutsertaan kita dalam pembangunan bangsa.

4. Perlu melakukan penelitian lebih lanjut tentang faktor-faktor lain yang mempengaruhi korupsi. 


\section{DAFTAR PUSTAKA}

Anti Corruption Clearing House (ACCH). (2018). "Penindakan". Diakses dari https://acch.kpk.go.id/id/statistik/tindak-pidana-korupsi

Badan Pengawasan Keuangan dan Pembangunan. (1999). Strategi Pemberantasan Korupsi. Jakarta: Badan Pengawasan Keuangan dan Pembangunan

Caiden, Gerald. (2000). The Essence of Public Service Professionalism; on Promoting Ethics in the Public Service. New York: United Nations

Hamzah, Andi. (2002). Pemberantasan Korupsi Ditinjau dari Hukum Pidana. Jakarta: Pusat Studi Hukum Pidana Universitas Trisakti

Hartati, Evi. (2007). Tindak Pidana Korupsi. Edisi kedua. Jakarta: Sinar Grafika

Kartono, Kartini. (1983). Patologi Sosial. Jakarta: Rajawali

Komisi Pemberantasan Korupsi. (2006). Memahami untuk Membasmi: Buku Saku Untuk Memahami Tindak Pidana Korupsi. Jakarta: Komisi Pemberantasan Korupsi (KPK)

Musianto, L.S. (2002). "Perbedaan Pendekatan Kuantitatif dengan Pendekatan Kualitatif dalam Metode Penelitian". Jurnal Manajemen E Kewirausabaan, (4) 2: 123-136

Marmosudjono, Sukarton. (1989). Penegakan Hukum di Negara Pancasila. Jakarta: Pustaka Kartini

Prinst, Darwan. (2002). Pemberantasan Tindak Pidana Korupsi. Bandung: Citra Aditya Bakti

Rahmah, Ghoida, dan Ali Akhmad Noor Hidayat (editor). (2018). "Ini Data Kenaikan Gaji PNS Sejak 2008 hingga Kini”. Diakses dari https://bisnis.tempo.co/read/1067247/ini-data-kenaikan-gaji-pns-sejak2008-hingga-kini

Shoim, Muhammad. (2009). "Pengaruh Pelayanan Publik Terhadap Tingkat Korupsi pada Lembaga Peradilan di Kota Semarang”. Laporan Penelitian Individual. Semarang: Pusat Penelitian IAIN Walisongo

Sugiyono. (2009). Metode Penelitian Kuantitatif, Kualitatif dan R E D. Bandung: Alfabeta

Sugiyono, dan E Wibowo. (2010). Statistika untuk Penelitian. Bandung: Alfabeta

\section{Undang-undang dan Peraturan}

Undang-undang Nomor 31 Tahun 1999 tentang Pemberantasan Tindak Pidana Korupsi.

Undang-undang Nomor 20 Tahun 2001 tentang Perubahan atas Undang-undang Nomor 31 Tahun 1999 tentang Pemberantasan Tindak Pidana Korupsi

Undang-undang Nomor 30 Tahun 2002 tentang Komisi Pemberantasan Tindak Pidana Korupsi

Undang-undang Nomor 5 Tahun 2014 tentang Aparatur Sipil Negara

Inpres No. 5 Tahun 2004 tentang Percepatan Pemberantasan Korupsi 


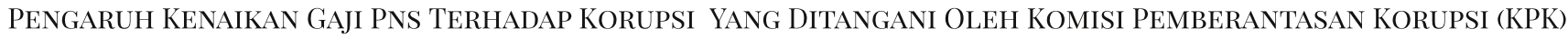

